\title{
Effect of temperature on the microstructure of fat globules and the immunoglobulin-mediated interactions between fat and bacteria in natural raw milk creaming
}

\author{
P. D’Incecco, ${ }^{\star} \dagger \ddagger$ L. Ong, $† \ddagger \S$ L. Pellegrino, ${ }^{*}$ F. Faoro,\# A. Barbiroli, ${ }^{*}$ and S. Gras $† \ddagger \S^{1}$ \\ *Department of Food, Environmental and Nutritional Sciences, University of Milan, 20133 Milan, Italy \\ †The Bio21 Molecular Science and Biotechnology Institute, The University of Melbourne, Parkville, Vic 3010, Australia \\ $\ddagger A R C$ Dairy Innovation Hub, Department of Chemical and Biomolecular Engineering, The University of Melbourne, Parkville, Vic 3010, Australia \\ §Particulate Fluid Processing Centre, Department of Chemical and Biomolecular Engineering, The University of Melbourne, Parkville, Vic 3010, \\ Australia \\ \#Department of Agricultural and Environmental Sciences-Production, Landscape, Agroenergy, University of Milan, 20133 Milan, Italy
}

\section{ABSTRACT}

Natural creaming of raw milk is the first step in production of Grana Padano and Parmigiano Reggiano Protected Denomination of Origin cheeses. This process decreases the fat content and plays an important role in the removal of clostridia species that may cause late-blowing defects in ripened cheeses. Partial coalescence of fat globules - that may influence fat behavior in cheese making and affect the microstructure of fat in the final cheese product - was observed at creaming temperatures higher than $22^{\circ} \mathrm{C}$ by confocal laser scanning microscopy. The widespread practice of heating of milk at $37^{\circ} \mathrm{C}$ before creaming at $8^{\circ} \mathrm{C}$ resulted in important changes in the size distribution of fat globules in raw milk, potentially altering the ability of fat to entrap clostridia spores. We investigated the role of immunoglobulin classes in both the clustering of fat globules and the agglutination of Clostridium tyrobutyricum to fat globules during creaming. Immunogold labeling and transmission electron microscopy showed that IgA and IgM but not IgG were involved in both clustering and agglutination. Both vegetative cells and spores were clearly shown to agglutinate to fat droplets, a process that was suppressed by thermal denaturation of the immunoglobulins. The debacterization of raw milk through natural creaming was improved by the addition of purified immunoglobulins. Overall, these findings provide not only a better understanding of the phenomena occurring during the natural creaming but also practical insights into how the process of creaming may be optimized in cheese production plants.

Key words: fat globule coalescence, microstructure, Clostridium tyrobutyricum, immunoglobulin

Received July 27, 2017.

Accepted November 30, 2017.

${ }^{1}$ Corresponding author: sgras@unimelb.edu.au

\section{INTRODUCTION}

Natural creaming occurs when the fat globules present in unagitated raw milk rise to the surface (Ma and Barbano, 2000). This process not only skims the milk but also eliminates somatic cells and spore-forming bacteria when the upper cream layer is removed (Dellaglio et al., 1969; Zacconi and Bottazzi, 1982; Geer and Barbano, 2014; D'Incecco et al., 2015). This purifying effect is important for cheeses such as Grana Padano and Parmigiano-Reggiano, where natural creaming represents the first step of the manufacturing process, as outlined in the product specification (European Union, 2011a,b). The spores remaining in the vat milk, including those of Clostridium tyrobutyricum, can germinate in cheese during ripening, causing a late-blowing defect that results in important economic losses (Bassi et al., 2009; D'Incecco et al., 2015).

Natural creaming is usually carried out within a broad temperature range from $8^{\circ} \mathrm{C}$ to $20^{\circ} \mathrm{C}$, with the actual temperature chosen by the cheesemaker on an empirical basis, mostly based on observation, with consideration of the season. The creaming temperature is critical, however, because it affects the tendency of fat globules to adopt a specific supramolecular organization; that is, to cluster or to coalesce (Fredrick et al., 2010). Clustering is thought to occur when 2 or more fat globules are in close contact for a substantial period, enabling the formation of stable aggregates. In contrast, coalescence involves the fusion of the membranes of 2 or more globules to form one larger unit, also arising because of contact between fat globules. When fat is partly solid, partial coalescence can also lead to the formation of fat clumps (Fredrick et al., 2010).

The clustering of fat globules is likely promoted by van der Waals forces, although studies have suggested that milk immunoglobulins may be involved in this phenomenon (Honkanen-Buzalski and Sandholm, 1981; 
Zacconi and Bottazzi, 1982; Euber and Brunner, 1984). Immunoglobulins and somatic cells also potentially contribute to the aggregation of fat globules with bacterial vegetative cells and spores during gravity separation. This moderation of bacterial and fat globule interactions by immunoglobulins has only been inferred indirectly, however, by the addition of colostrum as an immunoglobulin-enriched medium (Geer and Barbano, 2014).

Immunoglobulins, also known as antibodies, are synthesized by mammals in response to antigenic or immunogenic stimuli, such as bacteria and viruses, and provide protection against infection (Lilius and Marnila, 2001). They are $\sim 150 \mathrm{kDa}$ in size and comprise 2 identical heavy $(\sim 50 \mathrm{kDa})$ and 2 identical light $(\sim 25 \mathrm{kDa})$ polypeptide chains linked by disulfide bonds (Hurley and Theil, 2011). The protective bioactivity of these molecules varies but most act via an initial binding event. Typically, milk and colostrum contain 3 major types of immunoglobulin: IgG, IgM, and IgA. The most abundant immunoglobulin within bovine colostrum is IgG, which is present typically at $\sim 44 \mathrm{~g} / \mathrm{L}$, whereas $\operatorname{IgA}$ and IgM are each present at much lower concentrations of $\sim 4$ to $5 \mathrm{~g} / \mathrm{L}$ (Raducan, 2013).

This study sought to better understand the role of creaming in Grana Padano cheese making; in particular, the role of creaming in the elimination of spores in raw milk. We applied a holistic approach to study the creaming process, examining the effect of temperature on the supramolecular structure of fat globules and the role of the main immunoglobulin classes in promoting interactions between fat globules and the spores and vegetative cells of $C$. tyrobutyricum. The temperatures selected are of interest for Grana Padano cheese making. In addition, a trial including a rapid preheating step at $37^{\circ} \mathrm{C}$ was performed to simulate the so-called cold milk reactivation that is sometimes adopted by cheese factories before natural creaming.

\section{MATERIALS AND METHODS}

\section{Milk Samples}

Raw bulk milk was collected at a dairy farm of 100 Holstein cows in the north of Italy (Lodi, Italy) at the morning milking. Aliquots of $500 \mathrm{~mL}$ of milk were taken before refrigeration, brought to the laboratory (University of Milan) within $2 \mathrm{~h}$ of milking, and used for creaming trials with the addition of immunoglobulins. Colostrum for immunoglobulin purification was collected at the same dairy farm from heifers on d 2 postpartum. Freshly produced, raw, microfiltered, skimmed (0.3\% fat) milk was taken at an industrial plant (Tetrapack, Aarhus, Denmark), immediately fro- zen, and kept at $-18^{\circ} \mathrm{C}$ until use for creaming trials with addition of spore suspension.

Trials of natural creaming at different temperatures were carried out at the University of Melbourne. Raw bulk milk was collected from a local dairy manufacturer in Victoria (Australia). The bulk milk was pooled from different dairy farms from several cow breeds. The milk was collected and used within $1 \mathrm{~d}$.

\section{Purification of Immunoglobulins from Colostrum}

Native immunoglobulins were purified from colostrum by ammonium sulfate precipitation (Supplemental Figure S1; https://doi.org/10.3168/jds.2017 -13580). Briefly, the fat and caseins were removed from colostrum by centrifugation at $4,000 \times g$ at $4^{\circ} \mathrm{C}$ for 20 min after acidification to $\mathrm{pH}$ 4.6. Two protein fractions were successively precipitated from the skimmed whey colostrum with 45 and $80 \%\left(\mathrm{NH}_{4}\right)_{2} \mathrm{SO}_{4}$. The respective precipitates were analyzed by SDS-PAGE on a $12 \%$ gel using a Mini Protean 3 apparatus (Bio-Rad, Hercules, CA; Laemmli, 1970) to determine the optimal salt concentration for higher and more selective precipitation of immunoglobulins. The SDS-PAGE was conducted under both reducing and nonreducing conditions, as described by Barbiroli et al. (2013). Molecular weight (MW) markers (Amersham Biosciences, Amersham, UK) were used for calibration. Concentrated immunoglobulins (33.4 mg of protein $/ \mathrm{mL}$ ) were dialyzed using Spectra/Por dialysis tube [20,000 Da MW cut-off, 24 $\mathrm{mm}$ flat width, $1.8 \mathrm{~mL} / \mathrm{cm}$ (volume/length); Spectrum Laboratories Inc., Rancho Dominguez, CA] against 15 $\mathrm{m} M$ sodium phosphate buffer (PBS), $\mathrm{pH} 7.2$, containing $150 \mathrm{mM} \mathrm{NaCl}$ and used for natural creaming trials.

\section{Natural Creaming Trials}

Three natural creaming trials were carried out, at the laboratory scale, to produce cream samples destined to confocal laser scanning microscopy (CLSM), immunogold labeling (IGL) for transmission electron microscopy (TEM), and for an assessment of the spore count by the most probable number (MPN) method. In the first trial, 4 samples of $250 \mathrm{~mL}$ of raw milk were kept in graduated cylinders at $4^{\circ} \mathrm{C}, 8^{\circ} \mathrm{C}, 22^{\circ} \mathrm{C}$, or $40^{\circ} \mathrm{C}$. An additional sample was preheated at $37^{\circ} \mathrm{C}$ for $5 \mathrm{~min}$ in a thermostatic bath before creaming at $8^{\circ} \mathrm{C}$. The volume of cream that rose to the surface was visually evaluated using graduated cylinders at $0.5,1,3,6,8$, and $24 \mathrm{~h}$, as described by Farah and Rüegg (1991) and Franciosi et al. (2011), and the fat content of the 24-h samples was analyzed using the Babcock method, as described previously (Ong et al., 2010). This creaming trial was carried out in 5 replicate experiments; how- 
Table 1. Volume of cream and number of Clostridium tyrobutyricum spores (most probable number, MPN) determined in cream that rose during natural creaming of fat globules in microfiltered milk (MMilk) to which spores and immunoglobulins were added

\begin{tabular}{lcc}
\hline Sample $^{1}$ & $\begin{array}{c}\text { Cream } \\
(\mathrm{mL})\end{array}$ & $\begin{array}{c}\text { Spores } \\
(\mathrm{MPN} / \mathrm{mL})\end{array}$ \\
\hline MMilk + fat globules & $1.5 \pm 0.1$ & $\mathrm{NA}^{2}$ \\
Heated MMilk + fat globules & $1.1 \pm 0.1$ & $\mathrm{NA}^{\mathrm{a}}$ \\
MMilk + fat globules + spores & $1.5 \pm 0.1$ & $317 \pm 12^{\mathrm{a}}$ \\
Heated MMilk + fat globules + spores & $1.1 \pm 0.2$ & $87 \pm 6.0^{\mathrm{b}}$ \\
MMilk + fat globules + spores + Ig & $1.5 \pm 0.1$ & $537 \pm 80^{\mathrm{c}}$ \\
Heated MMilk + fat globules + spores + heated Ig & $0.0 \pm 0.0$ & $83 \pm 6.0^{\mathrm{b}}$ \\
\hline
\end{tabular}

${ }^{\mathrm{a}-\mathrm{c}}$ Means in the same column with different letters are significantly different $(P<0.05)$.

${ }^{1}$ In control samples, the milk was heated to $80^{\circ} \mathrm{C}$ for $10 \mathrm{~min}$ to inactivate Ig molecules (Heated MMilk). The spore data presented are the mean \pm standard deviations based on duplicate analysis of 3 creaming trials (n $=3)$.

${ }^{2} \mathrm{NA}=$ not applicable.

ever, the results presented are from duplicate analyses in which the shipping temperature of the milk from the farm to the laboratory was more closely controlled.

In the second trial, $25-\mathrm{mL}$ aliquots of raw milk were transferred into $25-\mathrm{mL}$ tubes, each with $1 \mathrm{~mL}$ of washed C. tyrobutyricum spore suspension, and carefully mixed by gentle inversion. The spore suspension was prepared as described by D'Incecco et al. (2015) and contained predominantly spores, together with some vegetative cells. The tubes were kept at $8^{\circ} \mathrm{C}$ for $12 \mathrm{~h}$ and then the bacteria-enriched cream layer was gently removed using a spatula for inclusion within a resin and subsequent immunogold labeling. This creaming trial was performed in duplicate.

The third trial was designed to study the effect of immunoglobulins on the creaming of fat without the interference of other milk components. Purified immunoglobulins, washed fat globules, and washed C. tyrobutyricum spore suspensions were added to either raw microfiltered skim milk (MMilk) or $0.01 M$ PBS in $10-\mathrm{mL}$ tubes before natural creaming at $8^{\circ} \mathrm{C}$, as shown in Supplemental Figure S1 (https://doi.org/10.3168/ jds.2017-13580). Washed fat globules were prepared from cream separated from raw milk by centrifugation at $2,000 \times g$ at $10^{\circ} \mathrm{C}$ for $15 \mathrm{~min}$. Cream was diluted 5 times in $0.01 M$ PBS, gently stirred for $10 \mathrm{~min}$, and centrifuged under the same conditions. The washing was done 3 times and a final concentration of fat equal to $35 \mathrm{~g} / 100 \mathrm{~mL}$ was obtained in the washed cream. The spore-enriched suspension was washed twice in sterile $0.01 M$ PBS by centrifugation at $3,000 \times g$ for 10 min at room temperature. The prepared components were added to either MMilk or 0.01 M PBS to reach a final concentration of $3.5 \mathrm{~g}$ of fat $/ 100 \mathrm{~mL}, 0.5 \mathrm{~g}$ of immunoglobulins $/ 100 \mathrm{~mL}$, and $4 \times 10^{6}$ spores $/ 100 \mathrm{~mL}$, according to the experimental plan shown in Tables 1 and 2. A parallel set of samples was prepared using the same milk heated at $80^{\circ} \mathrm{C}$ for $10 \mathrm{~min}$ to inactivate the constitutive immunoglobulins; these immunoglobulins are referred to as heated immunoglobulins (Table 1). The MPN of C. tyrobutyricum spores in the top cream layer was evaluated using a previously described method (D'Incecco et al., 2015), together with the volume of cream that had risen after natural creaming at $8^{\circ} \mathrm{C}$ for $8 \mathrm{~h}$. These creaming trials were performed in triplicate.

\section{Confocal Laser Scanning Microscopy of Cream Samples}

Cream samples were stained with Nile red (SigmaAldrich, St. Louis, MO) so that observe the triacylglycerol core of fat globules. The Nile red solution (1 $\mathrm{mg} / \mathrm{mL}$ ) was prepared in dimethyl sulfoxide (Chem Supply, Gillman, Australia) and kept protected from light until use. Cream samples were initially diluted 1:5 with water at room temperature. Then, $900 \mu \mathrm{L}$ of sample was mixed with $100 \mu \mathrm{L}$ of Nile red solution and incubated for $15 \mathrm{~min}$ at room temperature. An inverted confocal laser scanning microscope from Leica Microsystem (Heidelberg, Germany) was used, adopting the conditions described by Ong et al. (2010). Nile red was excited at $488 \mathrm{~nm}$ using an argon laser and the emission filter was set at 520 to $590 \mathrm{~nm}$.

\section{Transmission Electron Microscopy}

Cream samples and a culture of $C$. tyrobutyricum were embedded in resin for TEM. A $0.5-\mathrm{mL}$ aliquot of sample was mixed with $1.5 \mathrm{~mL}$ of fixative solution (glutaraldehyde $1 \%$, paraformaldehyde $4 \%$ in Na cacodylate buffer, wt/vol; Agar Scientific, Stansted, UK). The mixture was kept for $2 \mathrm{~h}$ at room temperature before mixing with $2 \mathrm{~mL}$ of low-temperature gelling agarose ( $2 \%$ in water, melted at $35-40^{\circ} \mathrm{C}$; VWR, Milan, Italy). The suspension was layered onto a microscope slide, allowed to set, and then cut into $1-\mathrm{mm}^{3}$ cubes. The cubes 
were further fixed in the same fixative solution for 30 min at $4^{\circ} \mathrm{C}$, washed with $0.1 \mathrm{M} \mathrm{Na}$ cacodylate buffer for $1 \mathrm{~h}$, and post-fixed in osmium tetroxide (1\% wt/vol in water; EMS, Hatfield, PA) for 2 h. Dehydration was carried out in a series of ethanol solutions, then samples were embedded in Spurr resin (EMS) and cured at $60^{\circ} \mathrm{C}$ for $24 \mathrm{~h}$. Ultrathin sections, 50 to $60 \mathrm{~nm}$ thick, were cut and stained with uranyl acetate and lead citrate (both $0.2 \%$ in water, wt/vol; EMS), and examined with a Philips E208 transmission electron microscope (Philips Technology, Aachen, Germany).

\section{Immunogold Labeling}

Thin sections prepared for TEM were incubated at room temperature for $5 \mathrm{~min}$ in $50 \mathrm{mmol}$ of PBS containing 1\% BSA and $0.01 \%$ Tween 20 (both Aurion, Wageningen, the Netherlands) before staining. The sections were then incubated at $4^{\circ} \mathrm{C}$ for 12 or $24 \mathrm{~h}$ in the primary anti-serum to cow $\operatorname{IgG}$, IgM, or IgA that had been raised in rabbit (Thermo Fisher Scientific, Waltham, MA); these antisera were diluted 1:100 or 1:1,000 in $50 \mathrm{mmol}$ of PBS. After careful washing with PBS, the sections were incubated at room temperature for $2 \mathrm{~h}$ in a 15-nm colloidal-gold labeled secondary antirabbit serum that had been raised in goat (Thermo Fisher Scientific).

\section{Image Analysis}

Three-dimensional (3D) CLSM images of cream samples were reconstructed using Imaris image analysis software (Bitplane, South Windsor, CT). Each 3D image consists of 40 layers of $512 \times 512$ pixels that are stacked together with a distance between layers of 0.25 $\mu \mathrm{m}$. The volume of the fat globules in the cream was calculated using Image J software (Research Services Branch, National Institutes of Health and Medicine,
Bethesda, MD). Microsoft Excel (Microsoft Corp., Redmond, WA) was used to calculate the relative volume distribution of the fat globules.

\section{Statistical Analysis}

Statistical treatment of data was performed by SPSS Win 12.0 program (SPSS Inc./IBM Corp., Chicago, IL). A $t$-test was used to separate the mean values of spores in pairs of different creams. Regression analysis was performed where the temperature was assigned as the independent variable and the fat content or the cream volume as dependent variables. A $P<0.05$ was used as the significance limit.

\section{RESULTS AND DISCUSSION}

\section{Effect of Temperature on Natural Creaming of Milk}

Natural creaming trials were carried out over a 24-h period at temperatures relevant to Grana Padano production. As expected, the initial creaming rate was faster at higher temperatures (Walstra, 1995; Figure 1a). A cream layer was visible after $30 \mathrm{~min}$ in the sample preheated at $37^{\circ} \mathrm{C}$ and kept at $8^{\circ} \mathrm{C}$ or for samples kept at $22^{\circ} \mathrm{C}$ or $40^{\circ} \mathrm{C}$, consistent with observations in the literature of rapid creaming after milking (Fox et al., 2015). In contrast, samples kept at $4^{\circ} \mathrm{C}$ or $8^{\circ} \mathrm{C}$ developed a cream layer more slowly after incubation for more than $1 \mathrm{~h}$ (Figure 1a).

Temperature also affected the volume of the cream layer, and an increase in creaming temperature caused a reduction in the volume of cream collected after 24 $\mathrm{h}$ (Figure 1b). The fat content (on a $\% \mathrm{wt} / \mathrm{wt}$ basis) increased with temperature, however, due to the formation of a surface oil layer of melted triglycerides (Mortensen, 1983) that led to greater exclusion of the aqueous phase (Figure 1b). This free oil layer is expect-

Table 2. Volume of cream and number of Clostridium tyrobutyricum spores (most probable number, MPN) counted at the top or bottom of a model system where fat globules, spores, and immunoglobulins were added in different combinations to $0.01 \mathrm{M}$ PBS in the absence of other milk components

\begin{tabular}{lcc}
\hline Sample $^{1}$ & $\begin{array}{c}\text { Cream } \\
(\mathrm{mL})\end{array}$ & $\begin{array}{c}\text { Spores } \\
(\mathrm{MPN} / \mathrm{mL})\end{array}$ \\
\hline PBS + fat globules & $0.4 \pm 0.1$ & $\mathrm{NA}^{2}$ \\
PBS + fat globules + spores & $0.4 \pm 0.1$ & $213 \pm 6.0^{\mathrm{a}}$ \\
PBS + fat globules + spores + Ig & $0.5 \pm 0.1$ & $527 \pm 91^{\mathrm{b}}$ \\
PBS + fat globules + spores + Ig $\times 3$ & $0.6 \pm 0.1$ & $537 \pm 81^{\mathrm{b}}$ \\
PBS + spores & $\mathrm{NA}$ & $83 \pm 6.0^{\mathrm{c}}$ \\
PBS + spores + Ig & $\mathrm{NA}$ & $87 \pm 6.0^{\mathrm{c}}$ \\
PBS + spores + Ig (B) & $\mathrm{NA}$ & $327 \pm 15^{\mathrm{d}}$ \\
\hline
\end{tabular}

${ }^{\mathrm{a}-\mathrm{d}}$ Means in the same column with different letters are significantly different $(P<0.05)$.

${ }^{1}$ The spore data presented are the mean \pm standard deviation based on duplicate analysis of 3 creaming trials $(\mathrm{n}=3)$. Ig $\times 3=3$-fold-higher concentration of Ig; $(\mathrm{B})=$ sampled at the bottom of the liquid sample.

${ }^{2} \mathrm{NA}=$ not applicable. 

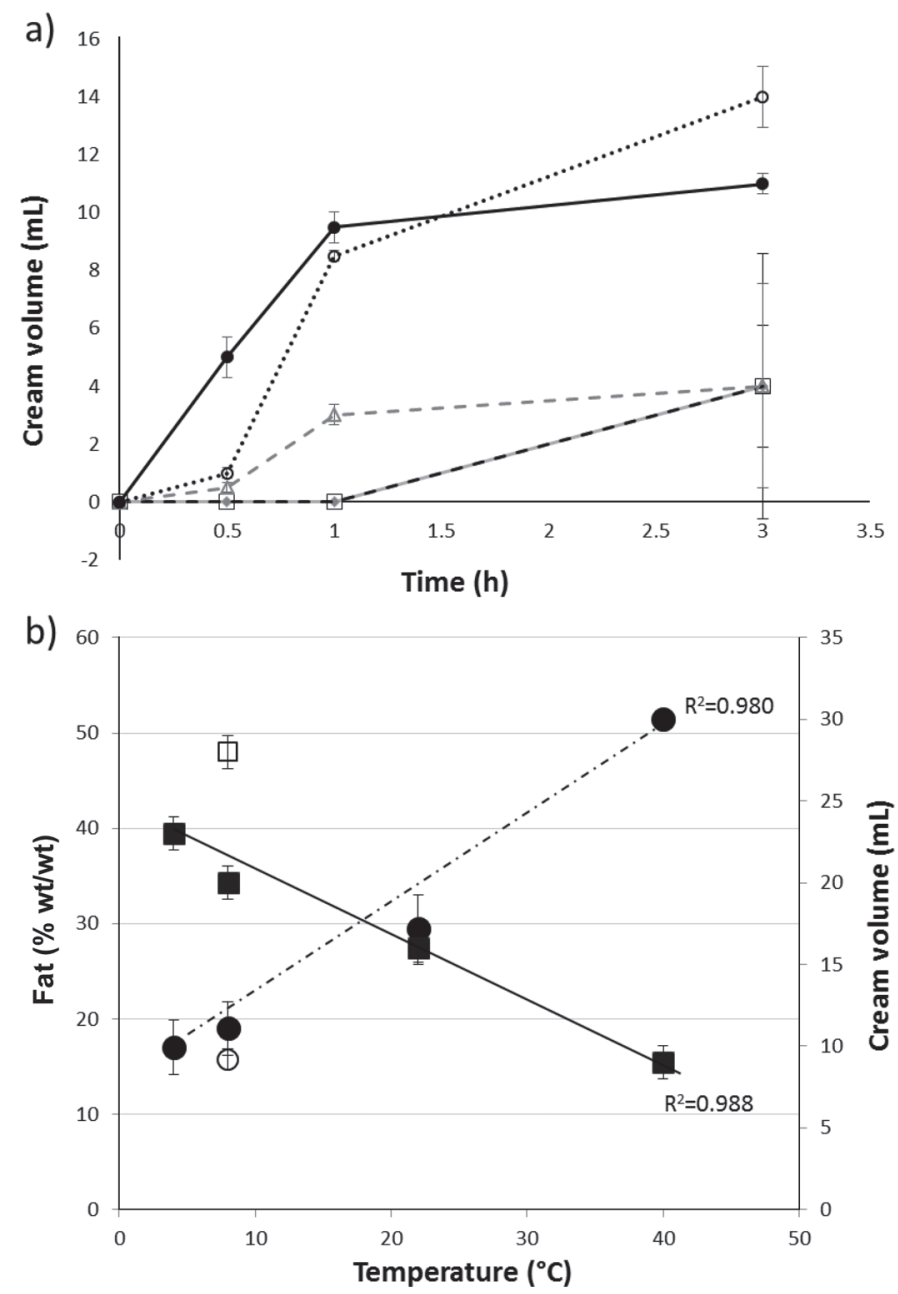

Figure 1. (a) Volume $(\mathrm{mL})$ of cream collected at various temperatures: $40^{\circ} \mathrm{C}(\bullet) ; 22^{\circ} \mathrm{C}(\mathrm{O})$; preheated to $37^{\circ} \mathrm{C}$ and creamed at $8^{\circ} \mathrm{C}(\boldsymbol{\Delta})$; $8^{\circ} \mathrm{C}(\checkmark)$; or $4^{\circ} \mathrm{C}(\square)$ during the first $3 \mathrm{~h}$ of natural creaming. The data are the average of 2 separate creaming trials. (b) Volume (ם) and fat content $(\bullet)$ of the cream layers obtained after $24 \mathrm{~h}$ of creaming. Sample preheated at $37^{\circ} \mathrm{C}$ and then creamed at $8^{\circ} \mathrm{C}(\square$, $\bigcirc$; volume and fat content, respectively). The data are the average of 2 separate creaming trials but are representative of a larger set of 5 replicate experiments. The error bars are the standard deviation of the mean The regression lines were calculated for the samples exposed to a single temperature excluding preheated samples $(\square, \bigcirc)$.

ed in raw milk after extensive fat globule coalescence has occurred (Walstra et al., 2005). The thermal history of the samples is also important to the process of creaming, and a significantly $(P<0.05)$ larger volume of cream was observed in the sample heated at $37^{\circ} \mathrm{C}$ before creaming at $8^{\circ} \mathrm{C}$ than in the sample just creamed at $8^{\circ} \mathrm{C}$.

Changes in the supramolecular organization of the fat during creaming at different temperatures were investigated by CLSM (Figure 2). Before creaming, distinct individual fat globules were observed in raw milk (Figure 2a). Only a small volume of the fat appeared in clusters or floccules and these aggregates were dispersed easily by shaking (see Supplemental Figure S2; https://doi.org/10.3168/jds.2017-13580). The fat globules in samples creamed at $4^{\circ} \mathrm{C}$ or $8^{\circ} \mathrm{C}$ appeared more concentrated than those in the initial milk (Figures $2 \mathrm{~b}$ and 2c), and the fat globule density was highest at a higher temperature (Figure 2c), consistent with the trend for fat content (\% wt/wt) obtained from chemical analysis of the cream layer (Figure 1b). Treatment of the milk at $37^{\circ} \mathrm{C}$ before creaming altered the supramolecular organization of the fat; the number of distinct individual fat globules decreased and extent of fat coalescence increased. Higher creaming temperatures also increased coalescence and this effect was most notable at $40^{\circ} \mathrm{C}$, where large clumps of intact globules appeared entrapped in the free oil (Figure 1f). Changes in the fat supramolecular organization were more extensive in the samples preheated at $37^{\circ} \mathrm{C}$ for 5 min before creaming at $8^{\circ} \mathrm{C}$ than in the samples creamed at $22^{\circ} \mathrm{C}$ with no preheating (Figure 1d vs. Figure 1e). This means that such thermal treatments, often performed by cheese makers, can damage the milk fat globules, although it should be noted that cheese makers typically apply heat in a continuous process whereas batch heating was applied here.

The clustering of fat droplets was also clearly visible in the rendered surfaces of the fat globules obtained from image analysis of the 3D CLSM images (Supplemental Figure S3; https://doi.org/10.3168/jds.2017 -13580). Greater coalescence was visible in the cream layer obtained after preheating at $37^{\circ} \mathrm{C}$ and creaming at $8^{\circ} \mathrm{C}$ or after creaming at $40^{\circ} \mathrm{C}$ without preheating than in all other samples (Supplemental Figure S3).

The size distribution of fat globules, obtained by analyzing $\sim 1,000$ fat globules per sample, is shown in Figure 3. A large population of native fat globules was present in raw milk but this population decreased as the creaming temperature increased and fat globules of increasing size were observed (Figure 3). A new population of coalesced fat with an average diameter of $\sim 28 \mu \mathrm{m}$ was observed in samples preheated at $37^{\circ} \mathrm{C}$ and creamed at $8^{\circ} \mathrm{C}$ or in samples creamed at $40^{\circ} \mathrm{C}$. This population represented 20 and $39 \%$ of the total fat volume in these samples, respectively. Another separate small population ( $10 \%$ by fat volume) of fat $\sim 17 \mu \mathrm{m}$ in size was also observed in samples creamed at $40^{\circ} \mathrm{C}$. The supramolecular organization of milk fat observed is likely the result of several factors, including (1) the composition of the fat, in terms of fatty acids and triglycerides; (2) the composition and structural organization of the milk fat globule membrane; and (3) the size of the fat globules and the physical or thermal process history of the samples (Michalski et al., 2004; Lopez, 2011; Murthy et al., 2016; Et-Thakafy et al., 

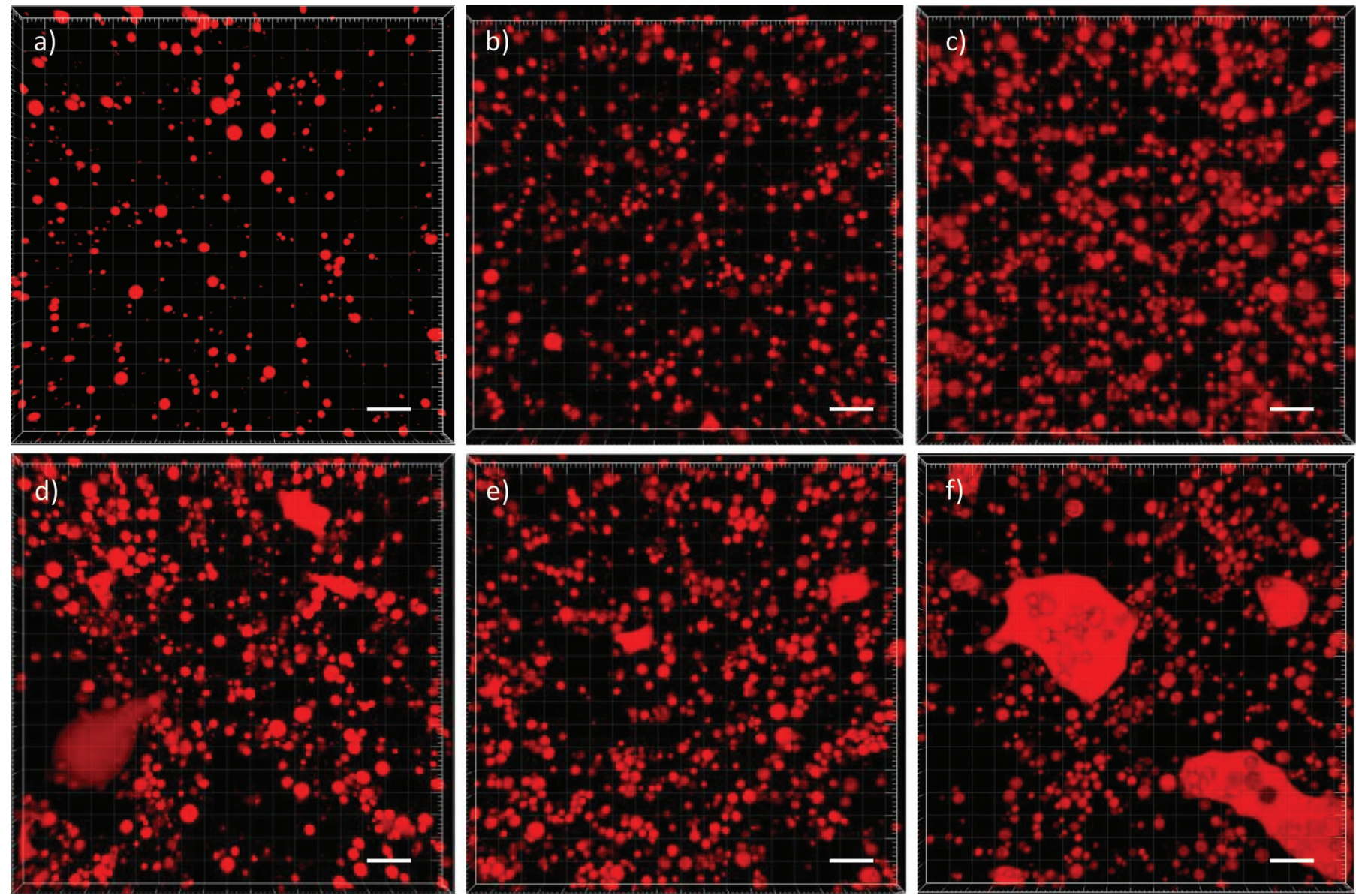

Figure 2. Microstructure of the fat within raw milk (a) and the surface cream layers collected after natural creaming at $4^{\circ} \mathrm{C}(\mathrm{b}), 8^{\circ} \mathrm{C}(\mathrm{c})$, milk that was preheated at $37^{\circ} \mathrm{C}$ and creamed at $8^{\circ} \mathrm{C}(\mathrm{d})$, or creamed at $22^{\circ} \mathrm{C}$ (e) or $40^{\circ} \mathrm{C}(\mathrm{f})$. The Nile red-stained fat globules appear gray (red). The scale bars are $20 \mu \mathrm{m}$ long. Color version available online.

2017). Each of these factors leads to a different ratio between liquid and solid fat. In our experiments, however, much of this variability was excluded by using the same source of milk in all trials. Overall, our investigation showed that the different temperatures adopted during natural creaming can induce different supramolecular organization of milk fat globules, independently of the other cited factors. Structural changes are also promoted because of the extended period of contact and proximity between fat globules within the creamed layer compared with that within milk (Fredrick et al., 2010).

Our observations of little coalescence occurring in creams containing 17 and $19 \%$ fat content here during creaming at $4^{\circ} \mathrm{C}$ or $8^{\circ} \mathrm{C}$ are consistent with those of Boode (1992), who showed that oil-water emulsions with a fat content $<25 \%$ are not prone to fat coalescence. The same study showed that tempering cycles from $5{ }^{\circ} \mathrm{C}$ to $30^{\circ} \mathrm{C}$ increased the tendency of emulsions to partial coalescence, because newly formed fat crystals tend to

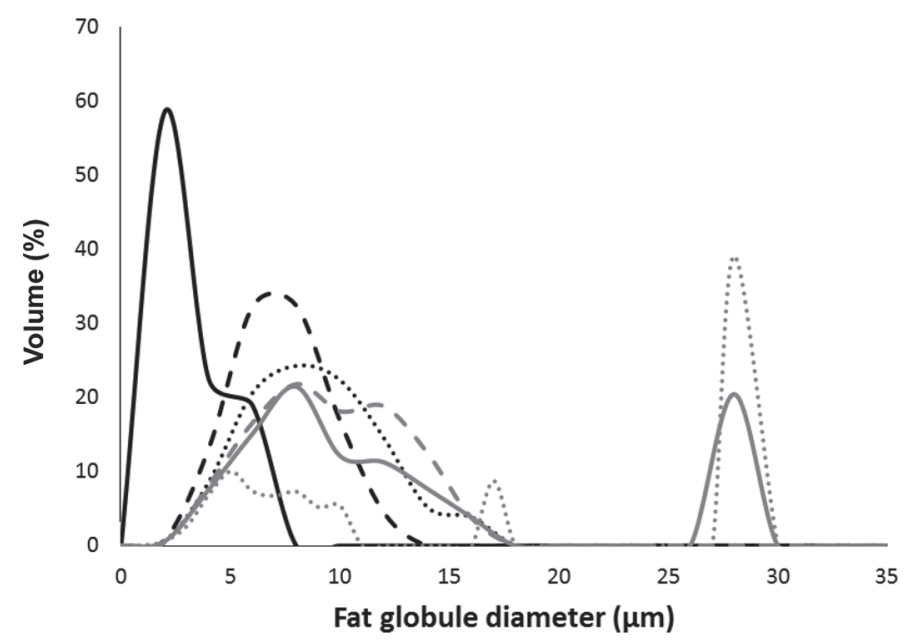

Figure 3. Volume distribution of fat globules obtained from image analysis of the 3-dimensional confocal laser scanning microscopy images (Supplemental Figure S3; https://doi.org/10.3168/jds.2017-13580) of raw milk (solid black line), cream samples separated at $4^{\circ} \mathrm{C}$ (black dashed line), $8^{\circ} \mathrm{C}$ (black dotted line), $8^{\circ} \mathrm{C}$ and preheated $37^{\circ} \mathrm{C}$ (solid gray line), $22^{\circ} \mathrm{C}$ (gray dashed line) or $40^{\circ} \mathrm{C}$ (gray dotted line). 
reposition within the fat globule protruding into the aqueous phase. Our study also showed high levels of partial coalescence between fat globules and fat clumping in samples preheated at $37^{\circ} \mathrm{C}$ before creaming at $8^{\circ} \mathrm{C}$. More recently, Moens et al. (2016) demonstrated, by light microscopy, that commercial cream showed little or no aggregation of fat globules after tempering at $20^{\circ} \mathrm{C}$, whereas some fat clusters occurred at $30^{\circ} \mathrm{C}$, consistent with our observations.

Although a study of the different supramolecular organizations of fat was not the main aim of the current study, our results clearly indicate that high creaming temperatures and tempering before creaming at low temperatures caused significant changes to the organization of fat globules. These changes, in turn, can affect Grana Padano cheese making, as they can affect debacterization, which occurs as a result of fat globule aggregation and the removal of the cream layer before cheese production. Spores remaining in the skim milk might spoil the cheese, causing the late-blowing defect. Furthermore, reorganization of fat observed in the cream layer is also expected to take place in the partly skim milk at the end of creaming before Grana Padano production. This reorganized fat could affect the structure of the cheese and promote undesired lipolysis.

\section{Role of Immunoglobulins in Natural Creaming of Milk}

Immunoglobulins were purified from colostrum and a series of creaming trials performed using the purified proteins to investigate the role of immunoglobulins in the aggregation of fat globules and association with bacterial cells and spores during gravity separation. Transmission electron microscopy and IGL were used to investigate the role of single immunoglobulin classes in fat globule clustering and bacterial adhesion.

\section{Purification of Immunoglobulins from Colostrum}

The immunoglobulins used in this study were purified from colostrum collected on the second day postpartum, when the viscosity of this product decreases, allowing operations such as centrifugation or filtration (Tsioulpas et al., 2007). Two consecutive precipitations of protein using $\left(\mathrm{NH}_{4}\right)_{2} \mathrm{SO}_{4}$ (45 and 80\%) were applied with the aim of maximizing the immunoglobulin yield, which was assessed by SDS-PAGE. Protein bands were identified based on MW and their behavior under both reducing and nonreducing conditions. In the reducing SDS-PAGE gel (Figure 4a), both milk and milk colostrum contained the typical bands of casein $(\alpha-\mathrm{CN}$, $\beta-\mathrm{CN}, \kappa-\mathrm{CN})$ as well as those of $\beta-\mathrm{LG}$ and $\alpha-\mathrm{LA}$. The caseins were mostly absent in the colostrum whey.

Under reducing conditions, immunoglobulins are present in 2 different bands corresponding to heavy (Ig $\mathrm{HC}$ ) and light (Ig LC) chains, as the disulfide bonds linking these molecules are reduced (Figure 4a). The yield of immunoglobulins was highest and bands darkest after precipitation with $45 \%\left(\mathrm{NH}_{4}\right)_{2} \mathrm{SO}_{4}$. The heavy chains of the immunoglobulins migrated close to the $67-\mathrm{kDa}$ marker, similar to previous reports of a band at $\sim 66 \mathrm{kDa}$ (Patel et al., 2005). The light chains migrated slightly higher than previously reported at $\sim 23 \mathrm{kDa}$ (Patel et al., 2005). The MW of Ig HC and LC may vary
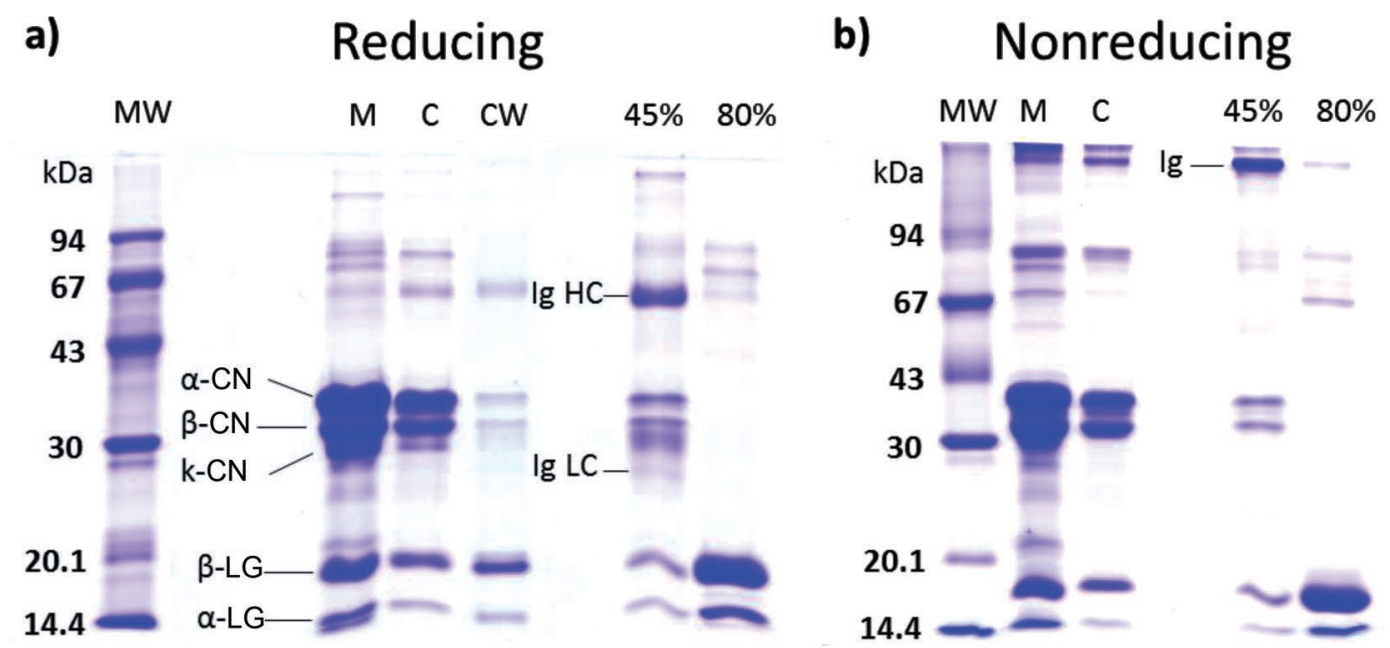

Figure 4. Sodium dodecyl sulfate-PAGE of purified immunoglobulin proteins under reducing (a) and nonreducing (b) conditions. M = milk; $\mathrm{C}=$ colostrum; $\mathrm{CW}=$ colostrum whey $45 \%=$ protein fraction precipitated with $45 \%\left(\mathrm{NH}_{4}\right)_{2} \mathrm{SO}_{4} ; 80 \%=$ protein fraction precipitated with $80 \%\left(\mathrm{NH}_{4}\right)_{2} \mathrm{SO}_{4}$ after an initial precipitation with $45 \%\left(\mathrm{NH}_{4}\right)_{2} \mathrm{SO}_{4} ; \mathrm{MW}=$ molecular weight markers. Major bands are identified; Ig $\mathrm{HC}=$ immunoglobulin heavy chains; Ig LC = immunoglobulin light chains. Color version available online. 
slightly with both glycosylation level and the presence of complement factors (Korhonen et al., 2000), consistent with these observations. The corresponding bands were absent in the nonreducing SDS-PAGE gel where a single band with a MW >100 kDa appeared, corresponding to whole immunoglobulin (Figure 4b; Farrell et al., 2004; Fuquay et al., 2011). Based on the electrophoretic patterns, precipitation at $45 \%\left(\mathrm{NH}_{4}\right)_{2} \mathrm{SO}_{4}$ led to the highest yield of immunoglobulins. Although some casein was present, the level of $\alpha-\mathrm{LA}$ and $\beta-\mathrm{LG}$ was lowest under these conditions. The addition of $80 \%$ $\left(\mathrm{NH}_{4}\right)_{2} \mathrm{SO}_{4}$ precipitated the whey proteins, especially $\alpha-\mathrm{LA}$ and $\beta-\mathrm{LG}$, without any further precipitation of the desired immunoglobulins (Figure 4). Consequently, the pellet obtained after the addition of $45 \%\left(\mathrm{NH}_{4}\right)_{2} \mathrm{SO}_{4}$ was used for further experiments.

In the last 2 decades, several techniques have been proposed to isolate immunoglobulins from colostrum or milk. The focus of these techniques, however, has been to separate immunoglobulin molecules, particularly in the case of column chromatography (El-Loly, 2007; Ayyar et al., 2012). Furthermore, some of these methods involve the exposure of immunoglobulins to heat, acid, or high pressure, which may negatively affect the molecular conformation and binding activity of the immunoglobulin molecules. The conditions adopted here allow immunoglobulins to be harvested in their native state, as shown in Figure 4b, potentially retaining the activity they would demonstrate in milk during creaming.

\section{Effects of Immunoglobulin Addition on Natural Creaming}

Purified immunoglobulins, washed fat globules, and washed spore suspension were added separately to microfiltered milk (MMilk; Table 1) or sterile PBS (Table 2) to assess the interaction between these components during creaming. The volume of the cream layer and number of $C$. tyrobutyricum spores were recorded after natural creaming for $8 \mathrm{~h}$ at $8^{\circ} \mathrm{C}$. In a set of parallel control experiments, milk samples were heated to $80^{\circ} \mathrm{C}$ for $10 \mathrm{~min}$ to inactivate the immunoglobulin molecules present.

A greater volume of cream was observed for MMilk samples with added fat globules than for the corresponding samples made of MMilk that had been heated at $80^{\circ} \mathrm{C}$ for 10 min before the addition of fat globules (Table 1). In addition, no cream layer was observed within the period of the experiment when the immunoglobulins naturally present in MMilk and those experimentally added were both thermally inactivated.

The number of spores in the cream layer was strongly dependent on whether the milk was heat treated be- fore the natural creaming experiment. Table 1 shows that a significantly $(P<0.05)$ lower number of spores was found in the cream layer of the MMilk sample with prior heat treatment than in unheated MMilk. The addition of immunoglobulins to unheated MMilk caused a significant $(P<0.05)$ increase in the number of spores captured in the cream layer compared with the same sample in which immunoglobulins were not added. The heat inactivation of both milk and added immunoglobulins also reduced the number of spores. Our results are consistent with those of Caplan et al. (2013), who showed that heat treatment at $\geq 76.9^{\circ} \mathrm{C}$ for $25 \mathrm{~s}$ impaired the separation or rising of spores and fat globules, possibly because of the denaturation of native immunoglobulins or the effect of heat treatment on the structure of the fat globules. The denaturation temperature for bovine milk immunoglobulins is reported to range from $62^{\circ} \mathrm{C}$ to $81^{\circ} \mathrm{C}$, when immunoglobulins are heated for few seconds (Mainer et al., 1997), consistent with the reduction of spores in the cream layer observed here.

A second set of experiments was carried out in a simpler model system, using PBS in the absence of other soluble components naturally present in milk, and measuring the effect of native immunoglobulins on the volume of cream and presence of spores.

The immunoglobulins appeared to mediate spore association with fat, as the number of spores in the cream layer increased after the addition of immunoglobulins compared with the sample without immunoglobulins (Table 2). The volume of cream did not appear to significantly change, similar to the milk system (Table 1) and as previous observed by Euber and Brunner (1984) in raw milk. Considering that 60 to $99 \%$ of bacteria concentrate in the cream layer during creaming (Abo-Elnaga et al., 1981; D'Incecco et al., 2015), the significant $(P<0.05) \sim 2$-fold increase in spores within the cream from $213 \pm 5.7$ to $527 \pm 90.7 \mathrm{MPN} / \mathrm{mL}$ observed in samples with and without immunoglobulins represents a significant enrichment and suggests that immunoglobulins are responsible for spore association (Table 2). Interestingly, when the amount of added immunoglobulins was increased 3-fold, the number of spores in the cream layer did not increase significantly. This observation suggests an efficient association of immunoglobulins with fat at physiologically relevant concentrations, and addition at free antigenic sites may not be available for further immunoglobulin binding at higher concentrations. It is worth noting that a significant number of spores $(\mathrm{MPN} / \mathrm{mL})$ were also found in the cream where immunoglobulins were not added, indicating that physical entrapment of spores within clusters of rising fat globules may also play an important role in milk desporification. 
In the absence of fat globules, the sample taken on top of the liquid milk contained a small number of spores, $83 \pm 6.0 \mathrm{MPN} / \mathrm{mL}$, not significantly different $(P<0.05)$ from that counted in the same sample where immunoglobulins were added. These experiments showed that fat globules are essential for spores to reach the top of the milk, because when they were not present, spores sedimented to the bottom layer of the milk due to their high density $\left(\sim 1.2 \mathrm{~kg} / \mathrm{dm}^{3}\right.$; Beaman et al., 1982), resulting in a high spore count of $327 \pm$ $15 \mathrm{MPN} / \mathrm{mL}$ in this bottom layer.

The immunoglobulins added to the MMmilk and PBS samples appeared to facilitate interactions between bacterial spores and fat globules, as higher numbers of spores were detected in the top cream layer in the presence of immunoglobulins. Previous studies have indirectly shown that immunoglobulins are responsible for fat globule association, and the tendency of some immunoglobulins to undergo cold-induced aggregation has led to them being considered cryoglobulins (Walstra, 1995). This supports our observation that fat globules appear more clustered at lower temperatures (Supplemental Figure S4; https://doi.org/10.3168/jds .2017-13580), likely facilitated by the association of immunoglobulin molecules. The ability of fat globules to stick together after the addition of serum components, likely antibodies, is well known (Babcock, 1889), as is the need for the presence of immunoglobulins for effective gravity-induced separation of fat globules (Euber and Brunner, 1984). Indeed, $7 \%$ of endogenous IgM is thought to be necessary for fat globule clustering. We have shown here for the first time that the addition of purified immunoglobulins improves spore capture during creaming, a significant observation given the need to remove spores naturally in some cheese processes, such as Grana Padano production.

\section{Identification of Immunoglobulin Classes by Immunogold Labeling}

Immunogold labeling experiments were conducted to further understand the role of immunoglobulin molecules in the clustering of fat globules and the agglutination of $C$. tyrobutyricum. An experiment was designed to determine whether all milk immunoglobulin classes (i.e., $\operatorname{IgG}$, IgM, and $\operatorname{Ig} \mathrm{A}$ ) are equally involved in promoting either fat globule clustering or the agglutination of bacteria to fat globules via association with immunoglobulins. Creaming trials were conducted in duplicate for each immunoglobulin class and IGL was performed on ultrathin sections of resin-embedded samples of cream obtained from raw milk with and without the addition of $C$. tyrobutyricum or pure cultures of $C$. tyrobutyricum as a control.
Transmission electron microscopy was used, because it not only allows an assessment of immunolabelling but also allows vegetative cells to be examined, unlike MPN counts. Immunoglobulin $\mathrm{M}$ was rarely observed in the interactions among fat globules and between globules and bacteria when observed by TEM; IgG was also absent from these sections (Supplemental Figure S5; https://doi.org/10.3168/jds.2017-13580). In contrast, $\operatorname{Ig} \mathrm{A}$ was consistently present in the material associated with the fat globules (Figure 5), between vegetative cells and fat globules (Figure 6), and between spores and fat globules (Figure 7). The material associated with the IgA molecules appeared to have low electron density (Figure 5a, 6a, and 7, as indicated by the arrows), as previously observed by D'Incecco et al. (2015). The material was also labeled with high numbers of gold particles (Figure 5b and 6b, indicated by the arrows), confirming the presence of IgA molecules.

Overall, these results show that immunoglobulin class IgA is involved in both the association of fat globules and the agglutination of vegetative cells and spores to fat globules. These observations are consistent with the hypothesis made by Caplan et al. (2013) that the surface of a fat globule may associate with another fat globule. In the presence of bacterial spores, these spores may also bind, replacing the direct interaction between fat globules and resulting in the entrapment of spores during creaming.

The TEM ultrathin sections of immunogold-labeled C. tyrobutyricum culture confirmed that IgA but not IgM or IgG immunogold-labeled probes directly associated with the cell walls of $C$. tyrobutyricum, indicating a high affinity between IgA and this bacterium (Figure 8).

It is important to emphasize the difference between the agglutination of bacteria to each other in the presence of serum $(\operatorname{Ig} \mathrm{A})$ and the association of a bacterium (vegetative cells or spores) with fat globules taking place during cream rising. The former is a biological event that should be expected, as it is part of the natural response of the immune system toward an antigen, thus not requiring any fat globule to be present. In fact, Hurley and Theil (2011) reported $\operatorname{IgA}$ as the major immunoglobulin class found in mucosal secretions that prevents infection by agglutinating microbes. Antimicrobial properties, such as the agglutination of microbes, were also reported for secretory IgM (Brandtzaeg and Johansen, 2007). This natural agglutinating activity was demonstrated in bovine colostrum preparations against a variety of pathogenic bacteria (Stephan et al., 1990; Loimaranta et al., 1998) and in normal milk and colostrum against lactic streptococci (Kanno et al., 1976). However, IgM activity appears less important than IgA activity in the experiments reported here. 

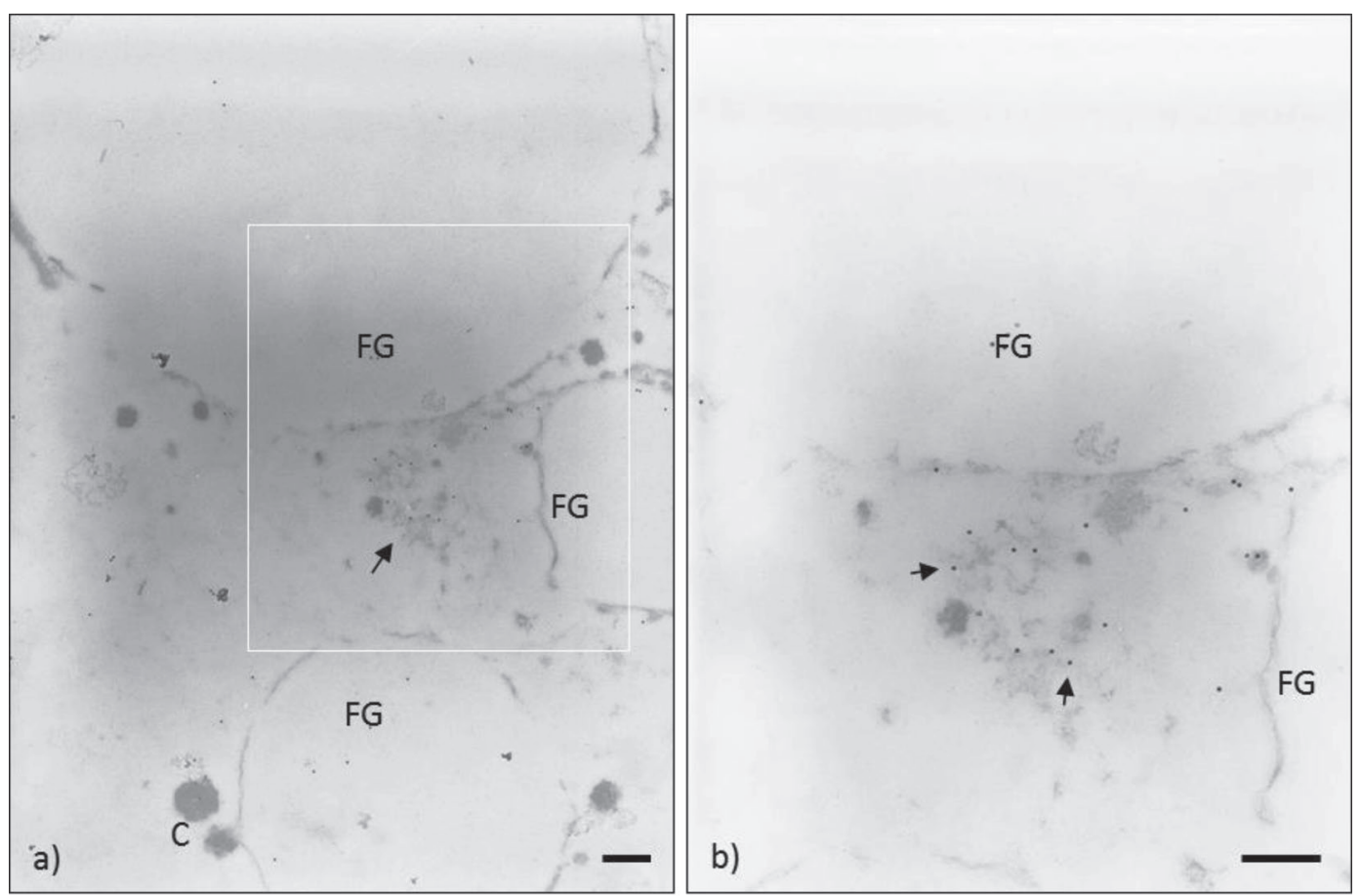

Figure 5. Transmission electron micrographs of an immunolabelled ultrathin section of fat globule (FG) clusters showing the presence of IgA in the amorphous material present between the fat globules (visible as black dots, indicated by the arrows). A higher magnification of the area framed in (a) is shown in (b) where the 15-nm gold-labeled IgA is clearly visible (as indicated by the arrows). C = casein micelle. The scale bars are $200 \mathrm{~nm}$ long. This image is representative of 3 different experiments.

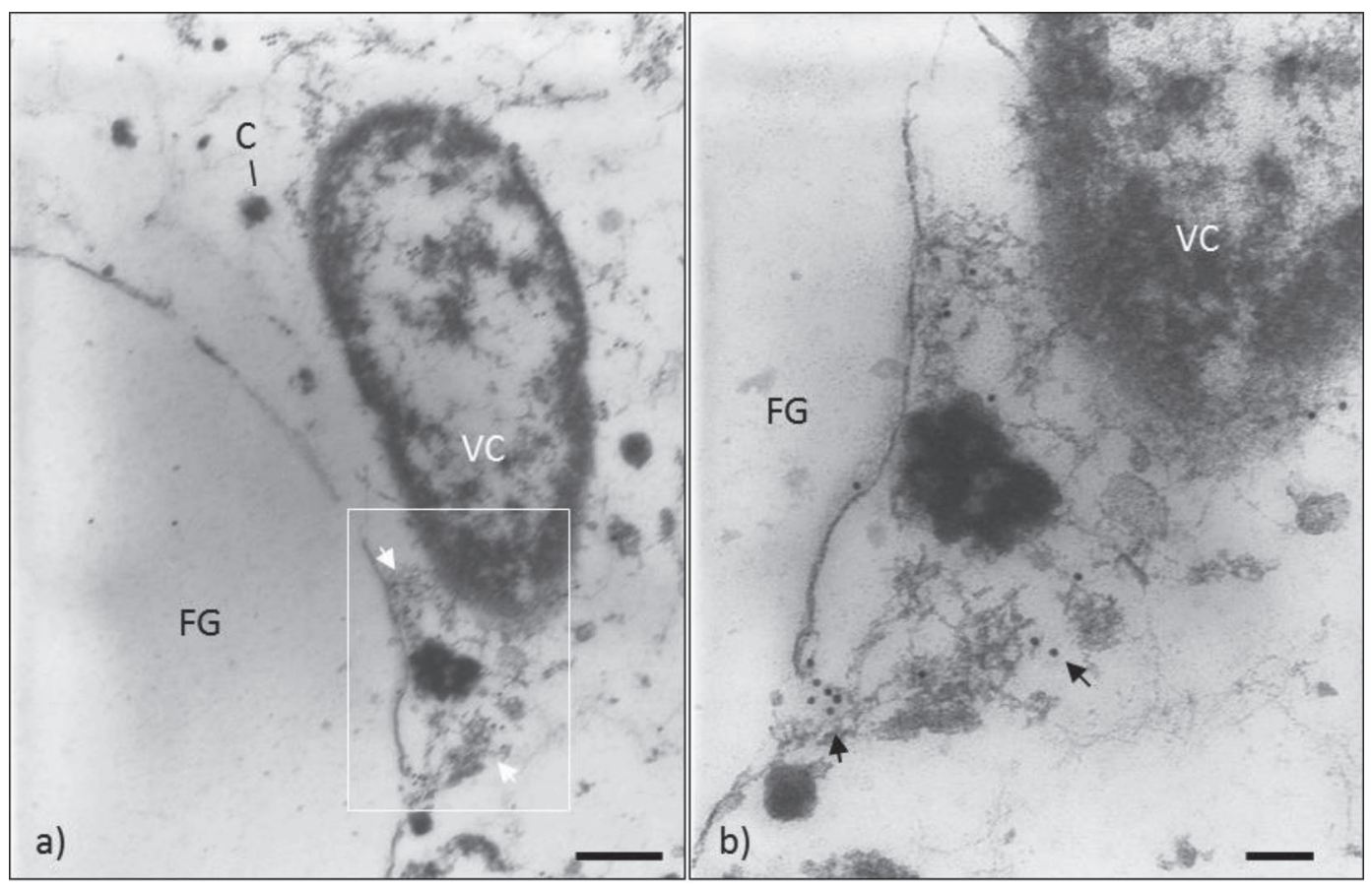

Figure 6. Transmission electron micrographs of an immunolabelled ultrathin section of a vegetative cell (VC) associated with a fat globule (FG) via amorphous material (white arrows; a). This material is labeled by 15-nm gold-labeled IgA antibodies (visible as black dots, indicated by the arrows; b); (b) is an enlarged framed area of (a) where the IgA antibodies are visible. $\mathrm{C}=$ casein micelle. The scale bars are $300 \mathrm{~nm}$ and $100 \mathrm{~nm}$ long in (a) and (b), respectively. This image is representative of 3 different experiments. 
The capture of bacteria during creaming is a poorly understood phenomenon that involves 2 steps: (1) the agglutination of bacteria to fat globules via association with IgA molecules, and (2) the subsequent rising of the 2 associated particles. The agglutination observed here implies a specific association between immunoglobulin and the surface antigens of $C$. tyrobutyricum and suggests that the ability of $C$. tyrobutyricum to agglutinate to fat globules is positively influenced by the presence of antigens on the surface of bacterial walls that act as ligands for IgA and, to a lesser extent, IgM molecules. Consequently, 2 further factors will influence the degree

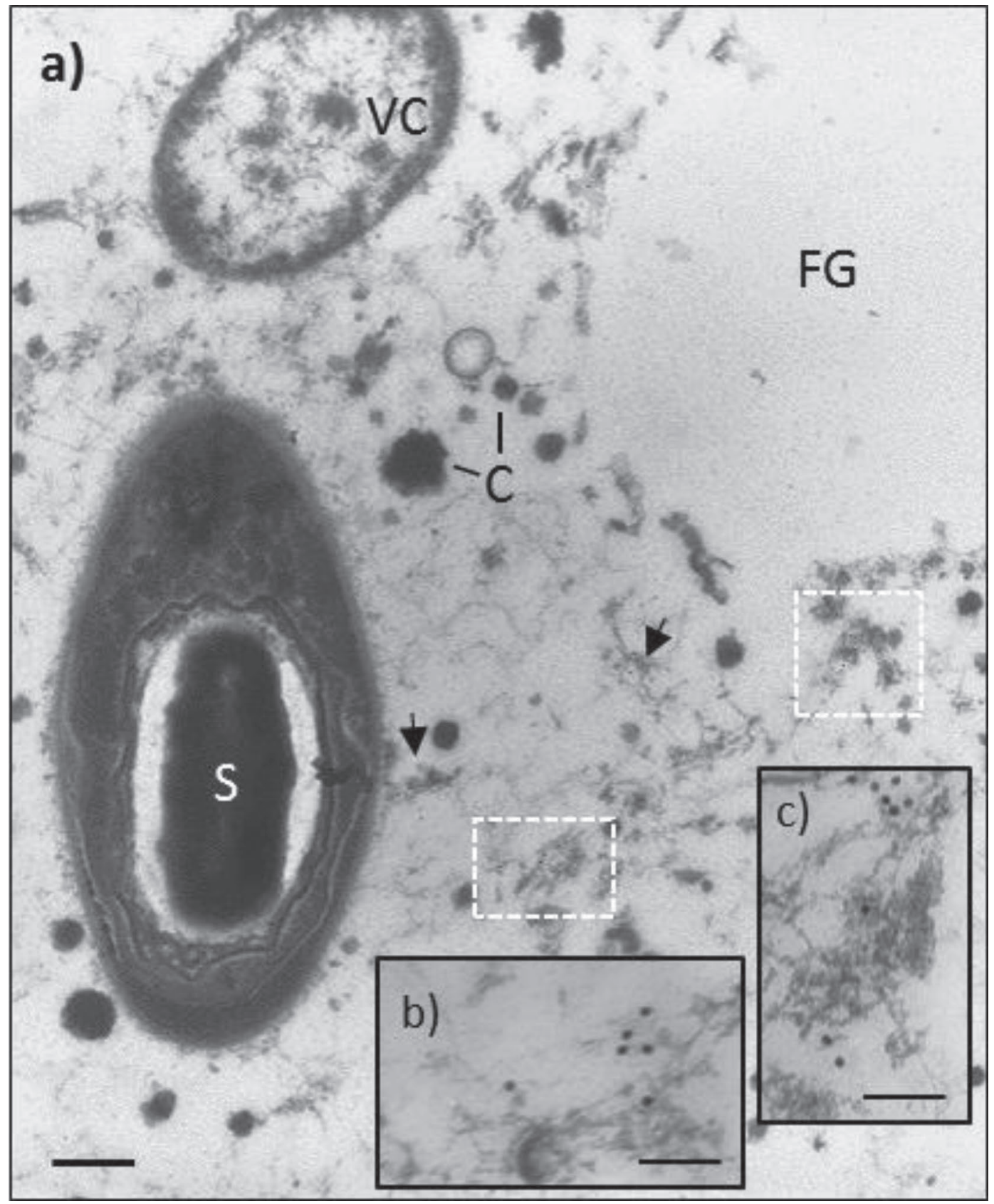

Figure 7. Transmission electron micrographs of an immunolabelled ultrathin section of a spore (S) and vegetative cell (VC) interacting with a fat globule (FG) via amorphous material (arrows; a). Gold-labeled IgA antibodies (black dots) on the amorphous material within the dashed lines are enlarged in panels (b) and (c). C = casein micelle. The scale bars are $300 \mathrm{~nm}$ long in (a) and $100 \mathrm{~nm}$ long in (b) and (c). This image is representative of 3 different experiments. 


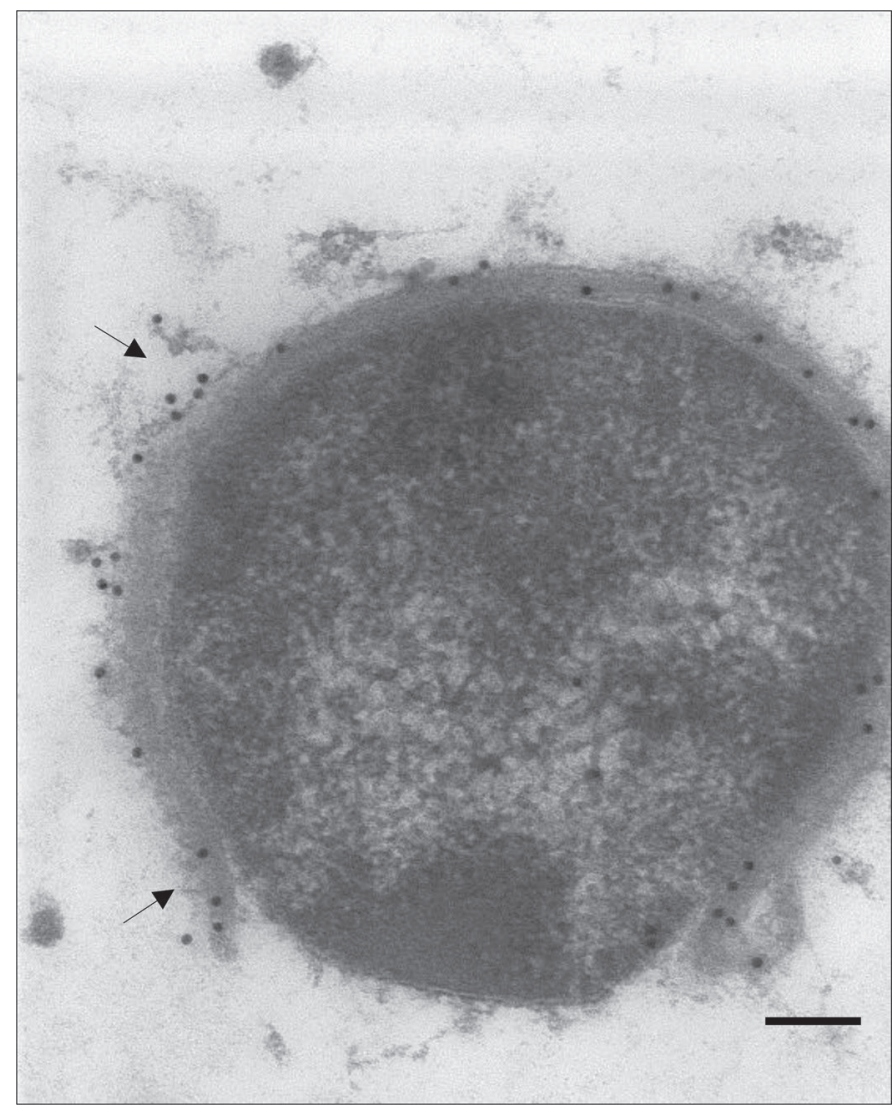

Figure 8. Transmission electron micrograph of immunolabelled ultrathin section of Clostridium tyrobutyricum vegetative cell. Immunogold labels $15 \mathrm{~nm}$ in diameter are shown in association with the IgA on the cell walls of $C$. tyrobutyricum (as indicated by the arrows). The scale bar is $100 \mathrm{~nm}$ long. This image is representative of 3 different experiments.

of agglutination: (1) the extent of antigen expression on the C. tyrobutyricum surface, and (2) the concentrations of $\operatorname{IgA}$ and IgM in the milk.

Very few studies have focused, directly or indirectly, on the agglutination of bacteria to fat globules during the natural creaming of milk. Franciosi et al. (2011) showed that psychrotrophic bacteria in milk intended for cheese making were mainly concentrated in the cream layer after natural creaming. Geer and Barbano (2014) showed that the addition of colostrum to skim milk was able to partially restore the natural rising of Clostridium spores in raw milk previously pasteurized at $76^{\circ} \mathrm{C}$ for $7 \mathrm{~min}$, suggesting the role of immunoglobulins. To our best knowledge, however, only Honkanen-Buzalski and Sandholm (1981) have shown that different immunoglobulin classes interact with milk bacteria. Consistent with our results, their study showed that Staphylococcus aureus appears to associate with fat globules within cream in the presence of $\operatorname{IgA}$ and IgM. No clustering and no bacterial agglutination were observed in the presence of $\operatorname{IgG}$, as observed in the current study for C. tyrobutyricum. Stadhouders and Hup (1970) also showed that the addition of an antibody-enriched preparation to a suspension of fat globules clearly increased the binding of Streptococcus cremoris but no creaming step was performed.

Our findings indicate that not all classes of milk immunoglobulins are involved in the association of fat globules and agglutination of $C$. tyrobutyricum to fat globules. An examination of the characteristics reported for immunoglobulins in the literature identified some possible explanations. Immunoglobulin A and IgM differ from IgG in both their physiological and structural features; IgA and $\operatorname{IgM}$ are found in bovine milk and colostrum in the form of secretory (s) $\operatorname{IgA}$ and $\operatorname{sIgM}$, which are produced predominantly by plasma cells in the mammary tissue (Hurley and Theil, 2011). The secretory component of sIgA and SIgM is a highly glycosylated polypeptide that plays a protective role within the immune system (Phalipon et al., 2002). Moreover, IgA and IgM are the only polymeric immunoglobulins, forming dimers and pentamers, respectively, in both milk and colostrum. In these polymeric structures, the monomeric units are covalently bound through a joining (J) chain (Mix et al., 2006; Kaetzel, 2007). This $\mathrm{J}$ chain also results in additional features, such as high valency of antigen-binding sites, allowing these molecules to effectively agglutinate bacteria. This high valency is likely also important in the role these immunoglobulin molecules play, facilitating interactions between fat globules and bacteria in creaming. Being monomeric, IgG lacks these characteristics. This may explain why $\operatorname{IgG}$ is not involved in any agglutinating or clustering phenomena observed during the natural creaming of milk.

\section{CONCLUSIONS}

Natural creaming of raw milk is the first step of Grana Padano cheese making. This study showed that natural creaming carried out at $22^{\circ} \mathrm{C}$ or $40^{\circ} \mathrm{C}$ induced coalescence, compromising the integrity of the native fat globule structure. This coalescence, in turn, could decrease the availability of the native milk fat globule surface for interfacial mechanisms during the natural creaming of milk. Such changes were also observed in milk that was heated at $37^{\circ} \mathrm{C}$ before creaming at $8^{\circ} \mathrm{C}$, indicating that the practice of cold milk reactivation may alter fat globules and change the creaming process, potentially also reducing the capacity of fat globules to entrap spores. Compared with cold agglutination, partial coalescence promotes formation of larger fat structures that cream faster. However, the rate of creaming will depend on the magnitude of the temperature-induced 
changes to bulk properties (density, viscosity) compared with magnitude of the same changes to individual fat globules from agglutination, clustering, or coalescence. We present an efficient method for immunoglobulin purification and demonstrated that IgA and, to a lesser extent, IgM were among the components responsible for the clustering of fat globules and agglutination of $C$. tyrobutyricum to fat globules during the natural creaming of milk. Clostridium tyrobutyricum showed a high affinity to $\operatorname{IgA}$ molecules, indicating that the natural variation in $\operatorname{Ig} \mathrm{A}$ and immunoglobulin concentration in milk could contribute to the variability in late-blowing defect. The addition of immunoglobulins to raw milk before natural creaming could also improve desporification, reducing the risk of late-blowing defect in Grana Padano or similar cheeses.

\section{ACKNOWLEDGMENTS}

This research was supported by the Australian Research Council's Industrial Transformation Research Program (ITRP) funding scheme (project number IH120100005). The ARC Dairy Innovation Hub is a collaboration between the University of Melbourne, The University of Queensland, and Dairy Innovation Australia Ltd. The authors thank The Advanced Microscopy Facility (AMF) and Biological Optical Microscopy Platform (BOMP) at The Bio21 Molecular Science and Biotechnology Institute and the Particular Fluids Processing Centre at the University of Melbourne for access to equipment.

\section{REFERENCES}

Aboelnaga, I. G., N. H. Metwally, and E. M. Elmansy. 1981. The bacterial content of creamed milk. Arch. Lebensmittelhyg. 32:19-21.

Ayyar, B. V., S. Arora, C. Murphy, and R. O'Kennedy. 2012. Affinity chromatography as a tool for antibody purification. Methods $56: 116-129$.

Babcock, S. M. 1889. The constitution of milk, and some of the conditions which affect the separation of cream. University of Wisconsin Agric. Exp. Sta. Bull 18:3-35.

Barbiroli, A., F. Bonomi, M. C. Casiraghi, S. Iametti, M. A. Pagani, and A. Marti. 2013. Process conditions affect starch structure and its interactions with proteins in rice pasta. Carbohydr. Polym. 92:1865-1872.

Bassi, D., F. Cappa, and P. S. Cocconcelli. 2009. A combination of a SEM technique and X-ray microanalysis for studying the spore germination process of Clostridium tyrobutyricum. Res. Microbiol. 160:322-329

Beaman, T. C., J. T. Greenamyre, T. R. Corner, H. S. Pankratz, and P. Gerhardt. 1982. Bacterial spore heat resistance correlated with water content, wet density, and protoplast/sporoplast volume ratio. J. Bacteriol. 150:870-877.

Boode, K. 1992. Partial coalescence in oil-in-water emulsions. PhD Diss. Wageningen Agric. Univ., Wageningen, the Netherlands.

Brandtzaeg, P., and F. E. Johansen. 2007. IgA and intestinal homeostasis. Pages 221-268 in Mucosal Immune Defense: Immunoglobulin. Springer US, New York, NY.
Caplan, Z., C. Melilli, and D. M. Barbano. 2013. Gravity separation of fat, somatic cells, and bacteria in raw and pasteurized milks. J. Dairy Sci. 96:2011-2019.

D'Incecco, P., F. Faoro, T. Silvetti, K. Schrader, and L. Pellegrino. 2015. Mechanisms of Clostridium tyrobutyricum removal through natural creaming of milk: A microscopy study. J. Dairy Sci. 98:5164-5172.

Dellaglio, F., J. Stadhouders, and G. Hup. 1969. Distribution of bacteria between the bottom, middle, and cream layers of creamed raw milk. Neth. Milk Dairy J. 23:140-145.

El-Loly, M. M. 2007. Identification and quantification of whey immunoglobulins by reversed phase chromatography. Int. J. Dairy Sci. 2:268-274.

Et-Thakafy, O., F. Guyomarc'h, and C. Lopez. 2017. Lipid domains in the milk fat globule membrane: Dynamics investigated in situ in milk in relation to temperature and time. Food Chem. 220:352361.

Euber, J. R., and J. R. Brunner. 1984. Reexamination of fat globule clustering and creaming in cow milk. J. Dairy Sci. 67:2821-2832.

European Union. 2011a. Regulation nr. 584, EU OJ nr. 160/65, 18 June 2011

European Union. 2011b. Regulation nr. 794, EU OJ nr. 204/19, 9 August 2011.

Farah, Z., and M. Rüegg. 1991. The creaming properties and size distribution of fat globules in camel milk. J. Dairy Sci. 74:2901-2904.

Farrell, H. M., R. Jimenez-Flores, G. T. Bleck, E. M. Brown, J. E. Butler, L. K. Creamer, C. L. Hicks, C. M. Hollar, K. F. Ng-KwaiHang, and H. E. Swaisgood. 2004. Nomenclature of the proteins of cows' milk —-Sixth revision. J. Dairy Sci. 87:1641-1674.

Fox, P. F., T. Uniacke-Lowe, P. L. H. McSweeney, and J. A. O'Mahony. 2015. Chemistry and biochemistry of cheese. Pages 69-143 in Dairy Chemistry and Biochemistry. Springer International Publishing, Cham, Switzerland.

Franciosi, E., G. De Sabbata, F. Gardini, A. Cavazza, and E. Poznanski. 2011. Changes in psychrotrophic microbial populations during milk creaming to produce Grana Trentino cheese. Food Microbiol. 28:43-51.

Fredrick, E., P. Walstra, and K. Dewettinck. 2010. Factors governing partial coalescence in oil-in-water emulsions. Adv. Colloid Interface Sci. 153:30-42.

Fuquay, J. W., P. F. Fox, and P. L. McSweeney. 2011. Encyclopedia of Dairy Science. Academic Press.

Geer, S. R., and D. M. Barbano. 2014. The effect of immunoglobulins and somatic cells on the gravity separation of fat, bacteria, and spores in pasteurized whole milk. J. Dairy Sci. 97:2027-2038.

Honkanen-Buzalski, T., and M. Sandholm. 1981. Trypsin-inhibitors in mastitic milk and colostrum: Correlation between trypsin-inhibitor capacity, bovine serum albumin and somatic cell contents. J. Dairy Res. 48:213-223.

Hurley, W. L., and P. K. Theil. 2011. Perspectives on immunoglobulins in colostrum and milk. Nutrients 3:442-474.

Kaetzel, C. S. 2007. Mucosal Immune Defense: Immunoglobulin A Springer, New York, NY.

Kanno, C., D. B. Emmons, V. R. Harwalkar, and J. A. Elliott. 1976. Purification and characterization of the agglutinating factor for lactic streptococci from bovine milk: IgM-immunoglobulin. J. Dairy Sci. 59:2036-2045.

Korhonen, H., P. Marnila, and H. S. Gill. 2000. Milk immunoglobulins and complement factors. Br. J. Nutr. 84:S75-80.

Laemmli, U. K. 1970. Cleavage of structural proteins during the assembly of the head of bacteriophage T4. Nature 227:680-685.

Lilius, E.-M., and P. Marnila. 2001. The role of colostral antibodies in prevention of microbial infections. Curr. Opin. Infect. Dis. 14:295-300.

Loimaranta, V., A. Carlen, J. Olsson, J. Tenovuo, E. L. Syvaoja, and H. Korhonen. 1998. Concentrated bovine colostral whey proteins from Streptococcus mutans/Strep. sobrinus immunized cows inhibit the adherence of Strep. mutans and promote the aggregation of mutans streptococci. J. Dairy Res. 65:599-607. 
Lopez, C. 2011. Milk fat globules enveloped by their biological membrane: Unique colloidal assemblies with a specific composition and structure. Curr. Opin. Colloid Interface Sci. 16:391-404.

Ma, Y., and D. M. Barbano. 2000. Gravity separation of raw bovine milk: Fat globule size distribution and fat content of milk fractions. J. Dairy Sci. 83:1719-1727.

Mainer, G., L. Sanchez, J. M. Ena, and M. Calvo. 1997. Kinetic and thermodynamic parameters for heat denaturation of bovine milk IgG, IgA and IgM. J. Food Sci. 62:1034-1038.

Michalski, M. C., M. Ollivon, V. Briard, N. Leconte, and C. Lopez. 2004. Native fat globules of different sizes selected from raw milk: Thermal and structural behavior. Chem. Phys. Lipids 132:247-261.

Mix, E., R. Goertsches, and U. K. Zett. 2006. Immunoglobulins-Basic considerations. J. Neurol. 253:V9-17.

Moens, K., A. K. M. Masum, and K. Dewettinck. 2016. Tempering of dairy emulsions: Partial coalescence and whipping properties. Int. Dairy J. 56:92-100.

Mortensen, B. K. 1983. Physical properties and modification of milk fat. Pages 159-194 in Developments in Dairy Chemistry. Vol. 2. P. F. Fox, ed. Applied Science, New York, NY.

Murthy, A.V.R., F. Guyomarc'h, and C. Lopez. 2016. The temperature-dependent physical state of polar lipids and their miscibility impact the topography and mechanical properties of bilayer models of the milk fat globule membrane. Biochim. Biophys. Acta Biomembr. 1858:2181-2190.

Ong, L., R. R. Dagastine, S. E. Kentish, and S. L. Gras. 2010. Transmission electron microscopy imaging of the microstructure of milk in cheddar cheese production under different processing conditions. Aust. J. Dairy Technol. 65:222-225.
Patel, H. A., H. Singh, P. Havea, T. Considine, and L. K. Creamer. 2005. Pressure-induced unfolding and aggregation of the proteins in whey protein concentrate solutions. J. Agric. Food Chem. 53:9590-9601.

Phalipon, A., A. Cardona, J. P. Kraehenbuhl, L. Edelman, P. J. Sansonetti, and B. Corthésy. 2002. Secretory component: A new role in secretory IgA-mediated immune exclusion in vivo. Immunity 17:107-115.

Raducan, G. 2013. The dynamic of immunoglobulin IgG, IgA and IgM type concentration in milk colostrum. Lucr. Stiint. Zooteh. Biotehnol. 46:309-311.

Stadhouders, J., and G. Hup. 1970. Complexity and specificity of euglobulin in relation to inhibition of bacteria and to cream rising. Ned. Melk-en Zuiveltijdschr. 24:79-95.

Stephan, W., H. Dichtelmüller, and R. Lissner. 1990. Antibodies from colostrum in oral immunotherapy. J. Clin. Chem. Clin. Biochem. $28: 19-23$

Tsioulpas, A., A. S. Grandison, and M. J. Lewis. 2007. Changes in physical properties of bovine milk from the colostrum period to early lactation. J. Dairy Sci. 90:5012-5017.

Walstra, P. 1995. Physical chemistry of milk fat globules. Adv. Dairy Chem. 2:131-178

Walstra, P., P. Walstra, J. T. Wouters, and T. J. Geurts. 2005. Dairy Sci. and Technol. CRC press.

Zacconi, C., and V. Bottazzi. 1982. Anticopri ed aggregazione dei globuli di grasso del latte. Sci. Tecn. Latt. Cas. 12:121-129. 